\title{
IDENTIFICATION OF BUSINESS ENTERPRISES BUMDES BASED ON SOCIAL AND ECONOMIC ASPECT (Case Study at BUMDes Ijen Lestari Tamansari Village District of Banyuwangi)
}

\author{
Moh. Hudi Setyobakti *)
}

\begin{abstract}
Law No. 6 of 2014 on Villages, provides an important position for the village to play its role in development. The important role of the village is the local authority possessed by the village in managing its household. Village economy is one of the important factors in assessing the success of village development. The village economic problems need to be solved by handling thoroughly, starting from the construction of infrastructure facilities, to developing the potential of the village to be optimized into opportunities for business opportunities that prosper the village community. Village Owned Enterprises, here in after referred to as BUMDes, become one of the important mandates contained in the Village Law. BUMDes urgency is affirmed in Permendesa number 4 of 2015. The context of BUMDes establishment is expected to be the driving force of the village economy, meaning that the establishment of BUMDes is not merely an orientation to the profit of the institution, but the more essence is the establishment of BUMDes should be able to provide both economic and social benefits to villagers.

The type of this research is descriptive qualitative, with the aim to identify and analyze the feasibility aspects of BUMDes business in terms of social and economic aspects. The results showed that BUMDesIjen Lestari Tamansarivillage District of Banyuwangi gave positive impacts economically and socially for the villagers like directly or indirectly. BUMDes's main business sector engaged in tourism management has an impact for residents around Ijen region, in the form of additional income from multiplayer tourism effects. The direct impact of BUMDes employees' involvement in the management of activities and community involvement in BUMDes businesses such as local food producers packed with BUMDes and community-based homestay managers.
\end{abstract}

Keywords: BUMDes, Social Aspect, Economic Aspect, Banyuwangi

\section{INTRODUCTION}

\subsection{Research Background}

The birth of Law No. 6 of 2014 on the Village, here in after referred to as the Village Law, provides an important position for the village to be able to play its role in national development. The important role of the village is the local authority possessed by the village in managing its household. This strategic role is then translated in the form of implementation of village development starting from the process of planning, implementation and accountability activities. The village government is expected to be more observant in recognizing all the problems and potential concerning the development of the village. Village economy is one of the important factors in assessing the success of village development. The village economic problem needs to be solved by handling thoroughly, starting from the construction of infrastructure facilities, to developing the potential of the village to be optimized into opportunities for business opportunities that prosper the village community.

Village Owned Enterprises, hereinafter referred to as BUMDes, become one of the important mandates contained in the Village Law. BUMDes's urgency is reinforced in the ministry-level technical regulations in this case implemented by the Village Ministry. Through Permendesa number 4 of 2015, re-affirmed about the importance of villages to build BUMDes. The context of BUMDes's establishment is expected to be the driving force of the village economy, meaning that the establishment of BUMDes is not merely an orientation to profit institution, but the more essential is the establishment of BUMDes should be able to provide benefits both economically and socially to the villagers. It is this factor that underlies the researcher's interest to research more about BUMDes's review of social and economic aspects of society. 


\subsection{Research Problem}

Here is several research problem that proposed by researcher:

1. Identify and analyze the feasibility aspects of BUMDes's business in terms of social aspects.

2. Identify and analyze the feasibility aspects of BUMDes's business in terms of economic aspects.

\subsection{Research Purpose}

This research aims to know and explain the feasibility aspects of BUMDes's business in terms of social and economic aspects.

\section{THEORETICAL FRAMEWORK AND HYPHOTESIS DEVELOPMENT \\ 2.1 Theoretical Framework}

\subsubsection{Village Development}

According to Siagian (2003), provides understanding of development as "a business or series of growth and change business which is planned and done consciously by a nation, State and government, towards modernity in the framework of nation building". In essence development is a deliberate activity between the government and involves the participation of the community in the direction of modernity with the direction of planning. According to Siagian (2003), "Village development is the wholeA series of efforts undertaken within the village environment with the aim of improving the living standards of rural communities and enhancing the welfare of the village ".

Based on this understanding, the development of the village is the development carried out in the lowest administrative area, namely the Village and the Village, the main characteristic of village development is the community participation in the development of the village or Kelurahan either directly in the form of self-help or self-help. The development is divided into two, namely physical development and non-physical development

\subsubsection{Rural Economic Development}

Khairuddin (2002: 29), states in general the component of the ideals of modern countries in the developed or developing world are the things that are essentially relative and difficult to imagine the achievement of an absolute "saturation point" which, once reached, does not may be upgraded such as:

1. Social justice

2. Equitable prosperity

3. The same treatment in the eyes of the law

4. Happiness mental, spiritual, and material

5. Happiness for all

6. Peace, and security

\subsubsection{BUMDes}

Permendesa number 4 of 2015, states that a Village Owned Enterprise, hereinafter called BUM Desa, is a business entity which is wholly or partly owned by the Village through direct participation derived from village wealth separated to manage assets, services and businesses Other for the greatest prosperity of the village community.

The establishment of BUM Desa is intended as an effort to accommodate the whole activities in the field of economy and / or public services managed by the Village and / or inter-village cooperation (Permendesa No 4, 2015, Chapter 2 Clause 2).

The establishment of BUMDes, oriented as a driver of the village economy. As an entity formed by the Village Government, BUMDes is not solely aimed at achieving profit, but how BUMDes can contribute in rural development, especially in the economic and social field.

In essence BUM Village Establishment aims (Permendesa No 4 2015, Chapter 2 Chapter 3):

1. Improve the village economy;

2. Optimize village assets to be useful for village welfare; 
3. Improve community efforts in managing the economic potential of the village;

4. Develop business cooperation plans between villages and / or with third parties;

5. Creating market opportunities and networks that support citizen's public service needs;

6. Open employment;

7. Improve the welfare of the community through improvements in public services, growth and equity of the village economy; and

8. Increase the income of the village community and the village's original income.

\subsubsection{BUMDes}

Permendesa Number 4 of 2015, states that a Village Owned Enterprise, here in after called BUM Desa, is a business entity which is wholly or partly owned by the Village through direct participation derived from village wealth separated to manage assets, services and businesses Other for the greatest prosperity of the village community.

\subsubsection{Feasibility Study}

According to Cashmere and Jakfar (2012), a business or business feasibility study is an activity that studies in depth about a business or business to be run, in order to determine whether or not the business is run.

Fahmi (2014), that business feasibility study is a science study that assesses the work of a business to be seen worthy or unfit to be implemented by placing qualitative and quantitative measures of size that are finally summarized in a recommendation.

Husnan and Muhammad (2014), that the feasibility study of a business project is a study of whether or not a business project can be implemented successfully.

Assessing business feasibility or business, done by assessing several aspects, including;

a. Legal aspect

With regard to the validity of the documents, the form of legal entity to the completeness of the operating permit permit.

b. Market and marketing aspect

Related to assess whether the entity that will invest in terms of marketing memeiliki expected market opportunities or not.

c. Financial aspect

Research in this aspect is done to assess what costs will be incurred and how much the costs will be incurred, the projected income and investment will return.

d. Technical aspects

In connection with the location of the business, determining the design of the layout of the building machine and so on up to the possibility of further development.

e. Aspects of management

Related to the business manager, personnel, organizational structure and main tasks and functions.

f. Social and economic aspects

Research in this aspect, to see how big the impact caused if the project run. This influence is primarily on the broader economy as well as the social impact on society as a whole.

g. Aspect of environmental impact

Assessing how the impact of the project if run on the surrounding environment both land, water and air. (Kasmir and Jakfar, 2012)

\subsubsection{Social and Economic Aspects of Feasibility Study}

Any business or business that is run will definitely give an impact, whether positive or negative. These impacts may apply internally or externally. Internally is related to the entity concerned while the external concerns to the community.

According to Kasmir and Jakfar (2012), an economic review is the extent to which business activities provide opportunities for both communities and governments to increase revenues or vice 
versa. The social impact for society in general is the availability of facilities and infrastructure needed. However, the social aspect also assesses possible negative impacts, such as demographic changes, cultural changes, customs, public health, lifestyle changes and other social structures. Outline the impact of economic aspects with the existence of a business or investment among others;

a. Can improve the household economy

b. Digging, regulating and using natural resource economies, through

c. Improving the local and regional government's economy

d. Regional development

The social impact with the existence of business or investment among others;

a. The existence of demographic changes, through the occurrence;

b. Cultural changes

c. Changes in public health

Based on the theoretical basis above can be concluded that, BUMDes as an economic entity founded by the Village Government, is an economic entity that must meet the business feasibility aspects, management by utilizing local resources that exist with attention to social and economic aspects, so BUMDes can contribute in a sustainable For village development in the village economic field that affects the welfare of rural communities.

\section{RESEARCH METHOD}

\subsection{Research Design}

The type of research used in this study is descriptive qualitative. By describing the obtained data which then elaborated in the form of explanation, then the data obtained are analyzed qualitatively, in this case the research must be active and using yourself as an instrument, following the assumptions of culture as well as following the data in an effort to achieve imaginative insight into the social world informant. Researchers are expected to be flexible and relational but still able to set distances. This research was conducted at BUMDes Ijen Lestari Desa Tamansari District of Banyuwangi District, with research object on identification of business feasibility of BUMDes based on social and economic aspect.

\subsection{Population and Sample}

The population in this study is the village in terms of a legal entity consisting of territory, community and village government involved directly or indirectly with the establishment and management of BUMDes. Samples were taken at random by taking participants from the Village Head, BUMDes Management, Mitra BUMDes, community groups, community leaders, and local communities and business actors in the village. Then field observations are drawn at random based on information submitted in the interview process. 


\subsection{Research Variables}

Table 1 Parameter of Research

\begin{tabular}{|l|l|}
\hline Variable & Parameter \\
\hline \multirow{5}{*}{ 1. Social Aspects } & 1. There is a demographic change \\
\cline { 2 - 2 } & 2. Cultural changes \\
\cline { 2 - 2 } & 3. Changes in public health \\
\hline 2. Economic Aspects & 1. Can improve the household economy \\
\cline { 2 - 2 } & 2. Digging, regulating and using natural resource economies \\
\cline { 2 - 2 } & 3. Improving the local and regional government's economy \\
\cline { 2 - 2 } & 4. Regional development \\
\hline
\end{tabular}

Source: Business Feasibility Study, Cashmere and Jakfar 2012

\subsection{Research Framework}

To get expected result of research, hence research model developed is as follows:

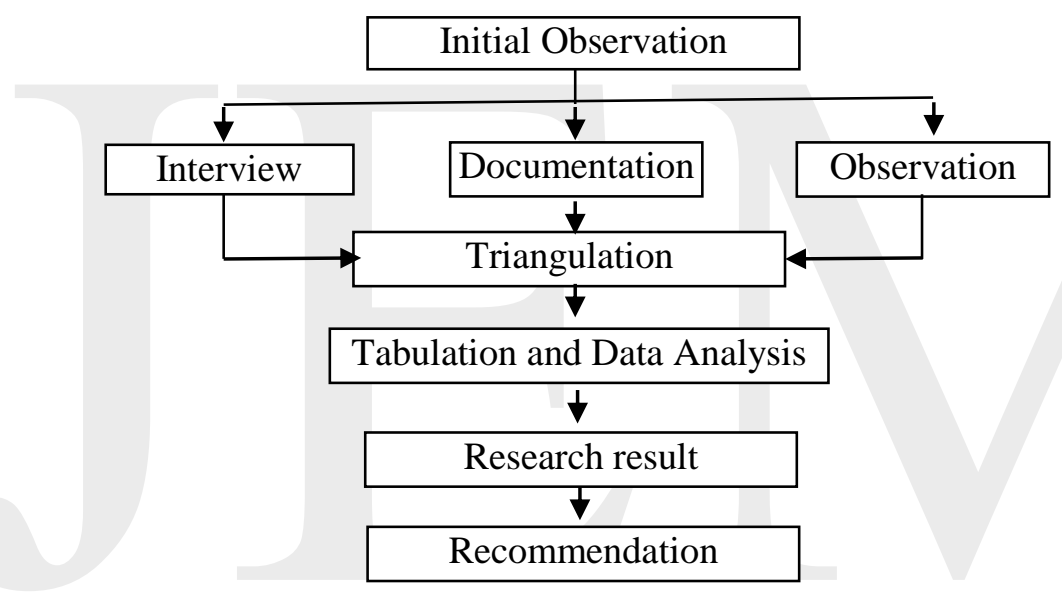

Picture 1 Research Framework

\subsection{Type of Data And Sampling Method}

This research using several ways or combine several techniques in collecting research data, includinh observation, documentation, and interview. Observation technique is done by observation frankly or disguised, that is to say frankly the purpose of observation and or sometimes also disguised, that is not to be straight forward deliver to the data source. Observations were made to obtain information on the management of BUMDes such as problems that still occur, felt or observed either directly or indirectly by the resource person. Observation is also done at the point of location by sampling based on information obtained by the researcher. This is an attempt to cross check information obtained from previous data collection steps. While, documentation techniques used in this research to study and document the rules that have, history of establishment and reporting existing.

This research also uses semi-structured interview techniques to find the problem more openly, where the party who invited the interview was asked opinions and ideas ideas, (Sugiyono, 2015, 73). Interviews were conducted on key village stakeholders, ie Village Heads, BUMDes Managers, MitraBUMDes, community groups, community leaders, and local communities as well as business actors in the villages with a view to exploring information on how the process of establishing BUMDes, Type of business BUMDes, BUMDes management, as well as social and economic impact for the village community. Interviews were also conducted in groups with the Focus Group 
Discussion approach or focus group discussions. This discussion involves the village administration, community representatives affected by BUMDes and BUMDes officials, with the aim of obtaining the full information based on information extracted from previous observations and interviews or deepening the information submitted by the resource persons.

\section{RESEARCH RESULT AND ANALYSIS}

Data analysis in this research is done in the following stages; 1) Placing information on different arrangement; 2) Create a matrix or category and place the evidence in that category; 3 ) Creating display data; 4) Make tabulation of different events; 5) examine the complexity of the tabulation created; And 6) compile information in chronological order (Miles and Huberman, 1992 in Kusuma and Purnamasari; 2016). The initial stage of the process of analyzing the data is to create a database to store copies of the information provided by the participants (Wahyuni, 2012). This research uses predecessors and successors as informants (kusuma and purnamasari, 2016).

According to Bryman and Bell (2007) in Chirico (2008), this research uses each data source and each participant as a tool to check each other. The use of two participants in each organization allows for comparison of the answers given by them. The use of other data sources (secondary data) allows further confirmation of the information provided by the participants (Bryman and Bell; 2007 in Chirico, 2008 in Kusuma and Purnamasari; 2016).

This research uses content analysis to answer research question. Content analysis is defined as a research method for subjective interpretation of data content through a systematic classification process of coding and identification of themes or patterns (Wahyuni, 2012). This method summarizes and classifies large amounts of data into categories that represent the same meaning (Weber, 1990 in Wahyuni, 2012 in Kusuma and Purnamasari, 2016).

The analysis process in this research focuses on the analysis of BUMDes feasibility identification based on social and economic aspects. The process of data analysis carried out with the following stages;

a. Develop an indicator matrix as the question material for participants

b. Gather information through interviews, documentation and observations

c. Make tabs and put the information on the same criteria

d. Testing the validity of data

e. Interpret data

\subsection{Validity}

Validity of data in qualitative research includes test; credibility (internal validity), transferability (external validity), dependability (reliability) and sonfirmability (objectivity). (Sugiyono, 2015). The validity of the data in this study using the approach of credibility and confirmability test.

\subsection{Credibility}

Test of credibility is done to get truth value of information obtained by researcher. The credibility test approach is done by extension of observation and triangulation. Extension of observation means the researcher returns to the field to do the naming, interview again with the source who ever met or new (Sugiyono, 2015). Triangulation in testing this credibility is interpreted as checking data from various sources in various ways and time. Triangulation approach used is triangulation technique, that is to test data obtained to the same source with different technique, for example data obtained by interview, then checked with observation and documentation (Sugiyono, 2015).

\subsection{Confirmability}

Confirmability testing in qualitative research is aimed to test the objectivity of the research. Research is said to be objective if the research results have been agreed by many people (Sugiyono, $2015 ; 131)$. At the process level in the field, the research agreement process is conducted in Focus 
Group Discussion or focus group discussions. Participants in the FGD are the parties who have become the research participants, so that obtained a complete and valid information. At the next level, the research was also tested by independent testers to test inputs, processes up to the results of the research. So get a joint agreement on the results of these studies.

\subsection{Research Discussion}

BUMDesa Ijen Lestari Tamansari village Licin district Banyuwangi regency, officially established in 2015. Initiation of establishment of BUMDes started in 2014. The process of establishing BUMDes Ijen sustainably through process stages that are not instant, this is reflected from the time required takes up to one year. There are several stages to be undertaken, especially the process of licensing and the drafting of village regulations through consultation to the relevant authorities in this regard SKPD.

At the beginning of establishment, BUMDes business activities based on Ijen region tourism management, namely the retribution of tourism. Starting from the tourism management activities then BUMDes can develop new business units including Rest area management, Culinary, Homestay and packing of local products in the form of coffee. Until now, BUMDes has developed the unit unit well and able to develop with indicators of growing business and add efforts of business units based on local wisdom, such as cooperation with local transport managers and water resources management planned for Swimming pool bathing tour. The success of BUMDes Ijen Lestari is also inseparable from the Village Government's evil in looking at opportunities and answering the challenges and accuracy in choosing a cadre that is used as a manager. According to the Village Chief of Tamansari, stated that "a process that is not instant and through the correct procedure becomes a force for the continuity of BUMDes Ijen Lestari plus precisely chooses a cadre of social entrepreneur spirit."

\subsubsection{Social Aspects Analysis}

Analysis of social aspect in this research, to see how far BUMDes Ijen sustain give social impact especially to society around activity management area by BUMDes. This is viewed from several parameters such as demographic changes, cultural changes, and impacts on public health.

a. Demographic changes

Establishment of BUMDes Ijen sustainable with business base on the management of ecotourism area, giving a positive impact on increasing labor force participation either directly or indirectly. Direct involvement of local communities in the management both as direct administrators and employees has provided employment opportunities for local communities. BUMDes business management indirectly also provides employment opportunities to local communities. Tourism management requiring service improvement in the form of lodging for visitors is realized by BUMDes by working with local people to make their homes homestay, meaning that there is job opportunity for residents to earn income from business management BUMDes. The packing of coffee products also gives residents the opportunity to sell coffee at BUMDes at a more adequate price. Multiplyer lan effects include the emergence of business enterprises stalls that support citizens of tourism management.

According to Bambang as chairman of BUMDes's board, "The establishment of homestay is able to provide employment opportunities of at least residents around the area of Tamansari rest area, then packing coffee has provided an opportunity for farmers to sell to BUMDes at a better price although not yet fully managed but gives hope population. Involvement of the people as a manager among others as a board, employees provide income for them "

b. Cultural change

Activity base BUMDes Ijen Lestari lies the power to maintain and strengthen the existence of natural resources and the value of local wisdom. Tourism activity of ijen area, is actually an activity that has been going before before the establishment of BUMDes Ijen Lestari. The birth of BUMDes has its roots in pre-existing activities. BUMDes further strengthens the management with the provision of tourism facilities and infrastructure, as well as strengthen 
the regulation or management norms, such as the existence of Village Rules that regulate the retribution of the tour so it is not wild.

The process of establishing BUMDes with the stages of community involvement from the needs assessment process to the deliberation of village meetings, until the establishment of the output of village regulations on the establishment of BUMDes, as well as the running of BUMDes management, provided a positive perception of the villagers and positive support from the community.

Based on these conditions, the birth of BUMDes strengthens the local culture of the village such as the value of local wisdom of the village such as the support of natural resource conservation and strengthening social capital of the community. This is reinforced by the statement of Yansen Pale, the village counselor on duty in the region, "the existence of BUMDes is an asset born to preserve local culture, improve tourist access services and reinvigorate social capital of society, with concrete examples of community involvement in decision making". This statement is also reinforced by Bambang as chairman of BUMDes, "BUMDes Ijen Lestari is very concerned about the value of cultural wisdom, until the smallest thing we noticed, such as how we look, how the guest service by providing drinks with trays, cups, teapots made from natural and nuanced local culture."

c. Changes in public health

Negative impact on the establishment of BUMDes Ijen Lestari, can be said nil or not. Because the base of BUMDes activity is not on the manufacturing business that manages the production on a large scale. According to community perceptions of the existence of BUMDes which actually strengthens the local potency of natural resources of the village, give impact to nature conservation. This means that the conservation of nature actually supports the sustainability of public health by making nature as a health lung.

\subsubsection{Economic Aspects Analysis}

Analysis of economic aspect in this research, to see how far BUMDes Ijen sustainably give economic impact, especially to village government and society around BUMDes management area. This is observed from several parameters such as improvement of household economy, regulation and utilization of natural resources economy, improvement of local government and regional government and regional development.

a. Improving the household economy

Tamansari Village community is a community culture with the main base of activity and daily livelihoods majority are farmers and gardening. This means that the community has previously had its main activities. Community involvement in BUMDes's business activities, such as community-based homestay management, community coffee packaging, additional income for residents. Thus there is a double income pattern from the role of farmers and the role of homestay owners as well as for people who sell coffee to BUMDes. In addition to the activities of the village tourist base, also provide multiplyer effect to the community, where people can also open a supportive business such as warung warung.

This is as expressed by one of the homestay owners "we are grateful for the establishment of BUMDes Ijen Lestari, by having our homestay have additional income besides we are farming or gardening, the management of this homestay we cooperate with BUMDes and of course must follow standard stipulation, Hygiene, service and so on, also we have cooperation agreement in the form of management sharing."

b. Digging, managing and using the natural resource economy

The main activities of BUMDes based on nature tourism, it automatically encourages the managers of BUMDes and the Village Government, how the natural attractions are still sustainable. So that the Village Government and BUMDes are interested in ensuring the sustainability of the business. Another consideration is, that the tourist area is partly located on the land area perhutani.

Related to this the Village Government and BUMDes, initiate the management cooperation 
with the Perhutani party. Then, to ensure that the management is environmentally oriented, the Village Government also initiates regulation, including the regulations on tourism retribution. This is as stated by the Village Head, "Tourism management by BUMDes has been shaded by the village regulations on retribution, so that from the retribution will be used as income for the village in carrying out the development such as supporting the tourism access including environmental conservation as well as the management of the land area Our perhutani has also entered into an MOU."

c. Improving the government economy both locally and regionally

BUMDes Ijen Lestari in accordance with existing village regulations, is an entity that is established and owned by the Village in this case the Village Government as a legal subject. This means that the Village Government has included village capital to BUMDes by majority. BUMDes's obligation is to contribute to the Village in the form of business results that are included in the village income and planned in the APBDesa.

So far, BUMDes has contributed revenue for the village and is used by the Village Government for Rural Development. Not only on the side of the village revenue handover, BUMDes also provides financial support for the activities of temporary activities organized by the village. This is in accordance with the information submitted by the Village Head and the BUMDes management. According to Bambang BUMDes, BUMDes said "BUMDes in the second year has been able to contribute to the income of the village and used for village development, besides the village celebration event, BUMDes also contributes financing activities."

d. Area Development

Access to tourism along with infrastructure developed by BUMDes, has opened the openness of the environment. These conditions have an impact on the equity of development, the openness of the social environment, the information so as to open the isolation of the territory and the horizon of the population. According to the local village head that since the management of BUMDes, the villagers have become more understanding about the importance of preserving nature, so even the public service must keep themselves so that bad influence does not happen, since it is getting more open, but so far all still keep the customs and customs And local local culture.

\section{RESEARCH CONCLUSION, LIMITATION, AND RECOMMENDATION}

\subsection{Conclusion}

The mandate of Law No. 6 of 2014, that the village can form BUMDes with a view to the prosperity of the village. BUMDes formed with the purpose of social business, meaning BUMDes not solely aimed at the aspect of profit or profit alone but also addressed in the framework of village development. The measure used to look at the impact is to look at the social and economic aspects, which are used in assessing the feasibility of the business. Approach This research is qualitative by describing the results of field data collection. Based on the research results found that BUMDes Ijen Lestari Desa Tamansari District Licin Banyuwangi District, judged from the feasibility of business from social and economic aspects to give a positive impact for the community. This means that in accordance with the mandate of law number 6 of 2014 and its derivative regulation, the existence of BUMDes Ijen Lestari has been in accordance with the purpose of its establishment. The key to the success of BUMDes management is lie on the ability of village leadership to see opportunities and answer existing challenges and to run in accordance with existing regulations and the ability to choose the right person as a manager, with the base of social entrepreneurship spirit. Another factor is that the sustainability of business activities is also based on activities and cultures that have been running in the community.

\subsection{Limitation}

The subjective prespective during this research may occur due to the effect of the researcher decision using interview and observation as their research instruments. 


\subsection{Recommendation}

Taking into account the conclusion of the research result, BUMDes business development needs to consider the value that has been developed in the community, so that BUMDes foundation will be stronger and get support from citizen participation. BUMDes remains to be managed professionally with a sound business management approach as well as transparent and responsible. Professional management should be supported with good manipulation tools, both system and managerial capacity that need to be continuously upgraded.

\section{REFERENCES}

Alfan, Syukran and Tauran. (2015). Jurnal Penelitian Dampak Kegiatan Badan Usaha Milik Desa (BumDesa) Bagi Masyarakat Desa Bareng Kecamatan Sugihwaras Kabupaten Bojonegoro. Accessed from http://ejournal.unesa.ac.id/article/18717/42/article.pdf.

Chirico, F. (2008). Knowledge Accumulation in Family Firms: Evidence from Four Case Studies. International Small Business Journal, $26: 433$.

Kasmir and Jakfar, (2012). Studi Kelayakan Bisnis, Edisi Revisi. Jakarta : Prenadamedia Group.

Khairuddin. (2002). Sketsa Kebijakan Desentralisasi Di Indonesia Format Masa Depan Otonomi Menuju Kemandirian Daerah. Malang : Averroes Press.

Kusuma, Gabriella Hanny and Purnamasari, Nurul. (2016). Jurnal Penelitian BUMDES: Kewirausahaan Sosial yang Berkelanjutan, Penabulu Jakarta. Accessed from http://jembatan tiga.com/wp-content/uploads/BUMDes-Kewirausahaan-Sosial-yang-Berkelanjutan.pdf.

Miles, M.B.and Huberman, A.M.. (1992). Analisis Data Kualitatif. Jakarta: UI Press.

Moleong, Lexy .J. (2006). Metode Penelitian Kualitatif Edisi Revisi. Bandung : PT. Remaja Rosdakarya.

Nawawi, Hadi. (2005). Metodologi Penelitian Sosial. Yogyakarta : Gajahmada University Pers.

Nurjanah, Santi. (2013). Jurnal Penelitian Studi Kelayakan Pengembangan Bisnis pada PT Dagang Jaya Jakarta, Journal The WINNERS, Vol. 14 No. 1. Acessed from on Maret 2013, http://Journal.Binus.ac.id/index.php/winners/article/download/641/618.

Permendesa No. 4 Year 2015 About Developing Village Index.

Samadi; ArrafiqurRahman; Afrizal. (2013). Jurnal Penelitian Peranan Badan Usaha Milik Desa (Bumdes) Dalam Peningkatan Ekonomi Masyarakat (Studi Pada Bumdes Desa Pekan Tebih Kecamatan Kepenuhan Hulu Kabupaten Rokan Hulu). Accessed from http://ejournal.upp.ac.id/index.php/fekon/article/view/378/384.

Siagian, Sondang P. (2003). Manajemen Sumber Daya Manusia. Jakarta : Bumi Aksara.

Sugiyono. (2015). Memahami Penelitian Kualitatif. Bandung : Penerbit Albeta.

Tama Dantika Ovi Era and Yanuardi. (2015). Jurnal Penelitian Dampak Badan Usaha Milik Desa (Bumdes) Bagi Kesejahteraan Masyarakat Di Desa Karangrejek Kecamatan Wonosari Kabupaten Gunung Kidul. Accessed from http://eprints.uny.ac.id/21714/9/9.Ringkasan.pdf.

Undang-Undang No. 6 Year 2014 About Village.

Wahyuni, S. (2012). Qualitative Research Method: Theory and Practice (Vol. 1). Jakarta: Penerbit Salemba Empat.

*) Moh. Hudi Setyobakti, STIE Widyagama Lumajang 